Piśmiennictwo zakonne $w$ dobie staropolskiej, red. Magdalena Kuran, Katarzyna KaczorScheitler i Michał Kuran, przy współpracy Dawida Szymczaka, Łódź 2013.

Bernadetta Puchalska-Dąbrowska ${ }^{1}$ Uniwersytet w Białymstoku

\title{
Charyzmat i święci Trzeciego Zakonu Świętego Franciszka w Kronikach trzech zakonów Marco da Lisboa z 1610 roku
}

Zgodnie z trynitarną doktryną świętych Augustyna (354-430) oraz Grzegorza Wielkiego (535-604) cała społeczność chrześcijańska dzieliła się na trzy klasy (stany): świeckich, kleryków oraz zakonników². W 1201 roku lombardzki ruch tak zwanych Pokornych przejął ów porządek, również stosując go do wszystkich chrześcijan ${ }^{3}$. Papież Innocenty III dokonał przesunięcia w pierwotnej hierarchii, umieszczając w pierwszej kolejności kleryków i zakonników, następnie braci świeckich i siostry konwerski, a na końcu przedstawicieli laikatu obojga płci ${ }^{4}$. Powyższa struktura, o charakterze historyczno-jurysdykcyjnym, stała się podstawą funkcjonowania w Kościele tak zwanych trzecich zakonów, czyli stowarzyszeń osób świeckich żyjących w duchu określonego instytutu zakonnego. Nie porzucając swych obowiązków rodzinnych i zawodowych, członkowie owych bractw utożsamiali się — poprzez zachowywanie rad ewangelicznych stosownie do swego stanu — z charyzmatem założyciela danego zakonu oraz jego duchowością. Charakterystyczny ubiór i przepisane regułą praktyki religijne umożliwiały życie na sposób zakonny osobom z różnych względów nie mającym możliwości wstąpienia do klasztoru.

Ważny krok w kierunku stworzenia laikatowi takiej ewentualności uczynił święty Franciszek z Asyżu, powszechnie uznawany za inicjatora trzech wielkich wspólnot: Braci Mniejszych, klauzurowych Sióstr Świętej Klary (klarysek) oraz świeckich „braci i sióstr od pokuty”, potocznie znanych pod nazwą Trzeciego Zakonu Świętego

\footnotetext{
${ }^{1}$ Bernadetta Puchalska-Dąbrowska, dr hab., absolwentka filologii polskiej i angielskiej. Pracuje w Instytucie Filologii Polskiej Uniwersytetu w Białymstoku. Prowadzi zajęcia na kierunkach filologia polska i angielska z historii dawnej literatury i kultury polskiej i brytyjskiej. Zainteresowania naukowe: polskie i angielskie dawne piśmiennictwo religijne i wspomnieniowe, obecność motywów angielskich w literaturze staropolskiej i polskich w piśmiennictwie angielskim, zagadnienia interdyscyplinarne (literatura a teologia, związki literatury z medycyna). Najważniejsze publikacje: Obraz dworów zachodnioeuropejskich w polskiej literaturze pamiętnikarskiej XVI i XVII wieku, Białystok 2000, Literatura angielska. Cz. I. Zarys dziejów, Białystok 2003, Bohaterowie Wysp Brytyjskich jako wzorce świętości w hagiografii polskiej XVI i XVII wieku, Białystok 2009.

${ }^{2}$ Źródta franciszkańskie, red. R. Prejs OFMCap, Z. Kijas OFMConv, Kraków 2005, s. 2355.

${ }^{3}$ Tamże, s. 2355.

${ }^{4}$ Tamże, s. 2355.
} 
Franciszka5. Tym samym franciszkański charyzmat realizował (i nadal realizuje się) w wyjątkowej różnorodności, wskazując przedstawicielom każdego stanu właściwe im sposoby angażowania się w życie chrześcijańskie.

Początki duchowego ruchu świeckich franciszkanów relacjonuje Tomasz z Celano, pierwszy biograf świętego założyciela, pisząc:

Ludzie każdego wieku i każdej płci podążali, by zobaczyć dziwy, jakich właśnie Pan dokonywał $\mathrm{w}$ świecie przez swojego sługę. [...] wielu zaniechało trosk światowych i pod wpływem życia i nauki świętego ojca Franciszka nabywało poznania siebie i zapragnęło miłości i czci dla Stwórcy.

Wielu z ludu, szlachcice i plebejusze, duchowni i świeccy, dotknięci tchnieniem Bożym, zaczęli garnąć się do świętego Franciszka, pragnąc na stale walczyć pod jego wodzą i kierownictwem. Święty Boży, jak rzeka pełna łaski niebieskiej zraszał ich wszystkich deszczem charyzmatów, a rolę ich serca zdobił kwiatami cnót. Oto wyborny mistrz! Na jego wezwanie odnawia się Kościół Chrystusowy obydwojga płci i zwycięsko kroczą trzy wojska dążących do zbawienia, według jego wzoru, reguły i nauki. Wszystkim podał normę życia i wskazał drogę zbawienia odpowiednią dla każdego stanu'.

Za pierwotny tekst normatywny regulujący życie członków Trzeciego Zakonu uważany jest List do wiernych, znany też jako Zachęta dla braci i sióstr pokutujących, zredagowany przez Poverella w dwóch wersjach — krótszej i rozszerzonej. Wprowadza on klarowny podział adresatów na „tych, którzy czynią pokutę” oraz „tych, którzy nie czynią pokuty"', przewidując nagrodę wieczną dla przedstawicieli pierwszej, zaś potępienie dla drugiej spośród wymienionych kategorii. W przekazie tym, składającym się w większości z fragmentów tekstów ewangelicznych, brak wyraźnych zaleceń odnośnie praktyk religijnych obowiązujących tercjarzy, ich stroju czy sposobu zachowania się.

Lukę tę wypełniają późniejsze reguły, jak Memoriale Propositi z 1221 roku, obejmująca podstawowe zalecenia doktrynalne i operatywne, przekształcająca początkowo spontaniczny ruch pokutników w konkretną strukturę $(\text { Ordo poenitentiae })^{8}$ oraz obszerniejsza Reguła Trzeciego Zakonu sygnowana przez papieża Mikołaja IV, pochodząca z 1289 roku. Oba teksty precyzują, w punktach, kwestie takie, jak: warunki przyjęcia, obrzędy inicjacji (obłóczyny, profesja), sposób życia (ubiór, uczestnictwo w wydarzeniach publicznych, posty, życie duchowe, stosunki z innymi członkami zakonu i wszystkimi ludźmi, troska o chorych i zmarłych), sprawa dyscypliny i wizytacji'. Obowiązywała ona do momentu wprowadzenia nowej reguły Leona XIII z 1883 roku, zastąpionej aktualnymi do dziś przepisami zatwierdzonymi przez Pawła VI w $1978^{10}$.

W okresie objętym niniejszymi rozważaniami, to jest czasach po Soborze Trydenckim, Trzeci Zakon Świętego Franciszka przeżywał swój renesans, co pozostawało w związku z ówczesnym odrodzeniem religijności świeckiej ${ }^{11}$. Dynamika życia duchowego laikatu znalazła swój wyraz w zjawisku powstawania licznych stowarzyszeń, jak

\footnotetext{
${ }^{5}$ Obecnie stosuje się nazwę: Franciszkański Zakon Świeckich.

${ }^{6}$ Żciorys pierwszy św. Franciszka, [w:] tamże, s. 469-470.

${ }^{7}$ List do wiernych, [w:] Źródta franciszkańskie, s. 227-231 (redakcja I) oraz s. 233-241 (redakcja II).

${ }^{8}$ Tamże, s. 2365-2373.

${ }^{9}$ Tamże, s. 2377-2392.

${ }^{10}$ Reguła i życie franciszkanów świeckich. Tekst Reguty i modlitwy, Warszawa 2003.

${ }^{11}$ K. Sokołowska, Świeckich drogi do świętości w hagiografii sarmacko-barokowej, Poznań 2008, s. 30.
} 
bractwo apostołów świeckich w Vincenzie, Stowarzyszenie Małżonków Antoniego Marii Zaccariego ${ }^{12}$, w Polsce Bractwo Miłosierdzia przy kościele świętej Barbary w Krakowie. Powstawały modlitewniki przeznaczone dla świeckich, pisane w językach narodowych, jak książka do nabożeństwa dla wspomnianego bractwa świętej Barbary (zredagowana przez Piotra Skargę) czy Harfa duchowna Marcina Laterny (pierwszy oryginalny modlitewnik w języku polskim, wydany w roku 1583 , zalecający modlitwę poranną, rozmyślanie, pracę i rachunek sumienia) ${ }^{13}$. Ukazujące się w okresie posoborowym zbiory hagiograficzne (z Żywotami świętych Piotra Skargi na czele, wydanymi po raz pierwszy w 1579 roku) wzbogacano o wzorce osobowe reprezentantów laikatu — władców, dowódców wojskowych, osób żyjących w małżeństwie i wdów ${ }^{14}$. Przełomowym wydarzeniem było opublikowanie w 1609 roku pierwszego podręcznika duchowości świeckiej — Filotei pióra biskupa Genewy, świętego Franciszka Salezego, zawierającej konkretne zalecenia w kwestii życia wewnętrznego, połączonego z wzorowym wypełnianiem obowiązków stanu. Sam autor świadomy był prekursorskiego charakteru swego dzieła, o czym świadczy następujący fragment przedmowy:

Moje zaś przedsięwzięcie i intencja jest tych w pobożności zaprawić, co w miastach, na dworach, przy gospodarstwie dni swoje pędzą, a dla stanu, w którym zostają, powierzchownie żywot pospolity z drugimi prowadzić muszą ${ }^{15}$.

Nie bez znaczenia, jak się wydaje, był również fakt przynależności autora traktatu do świeckiego Bractwa Paska Świętego Franciszka, grupującego — podobnie jak Trzeci Zakon - także osoby duchowne ${ }^{16}$.

O randze Trzeciego Zakonu jako istotnym odgałęzieniu rodziny franciszkańskiej, jak również jego znaczeniu w dziejach duchowości świadczy fakt poświęcenia mu uwagi w obszernym dziele franciszkanina Marka z Lizbony (Marco da Lisboa) Kroniki trzech Zakonów postanowionych od Ojca ś. Franciszka, przełożonym na język polski przez nieznanego zakonnika-bernardyna i wydanym w Krakowie w drukarni Andrzeja Piotrkowczyka w roku 1610. Dwutomowa książka ma charakter kompilacyjny, o czym świadczy formuła: „Z rozmaitych i pewnych autorów”, historyczny („w której się opisuje, co się w tych Zakonach przydawało") oraz utylitarny, ze wskazaniem na konkretne kategorie odbiorców (,ku pospolitemu pożytkowi Braciej Mniejszych i Sióstr św. Franciszka, i inszych ludzi nabożnych i do tych trzech zakonów skłonnych").

$\mathrm{Z}$ punktu widzenia podjętych rozważań najbardziej interesująca jest księga IX drugiej części wspomnianego dzieła, zatytułowana: Kroniki Braciej Mniejszej dziewiąte ksieggi, w których się opisuje postanowienie Reguty trzeciego zakonu, nazwanego Pokutujacych, przez świętego Franciszka zaczętego i żywoty wielu z tego zakonu, a zwtaszcza świętej Elżbiety Królowej Wegierskiej ${ }^{17}$.

\footnotetext{
${ }^{12}$ Tamże, s. 30.

${ }^{13}$ Tamże, s. 30.

${ }^{14}$ Tamże, s. 57-113, 115-184.

${ }^{15}$ F. Salezy, Philotea, czyli droga do pobożności. Wszystkim każdego stanu i kondycji ludziom slużąca, przekł. K. Herka, Kraków 1741, s. C.

${ }^{16}$ T. Słotwiński OFM, M. Damian OFM, Święci franciszkańscy na każdy dzień, Wrocław 2008, s. 47-48.

${ }^{17}$ Kroniki trzech Zakonów postanowionych od Ojca śwwiętego Franciszka, wtóra część. Na dziesięć Ksiag rozdzielona, Kraków 1610, s. 405.
} 
Kompozycja księgi obejmuje jedenaście rozdziałów, z których cztery tworzą część historyczno-normatywną (dzieje powstania franciszkańskiego ruchu świeckich, teksty dokumentów papieskich potwierdzających kanoniczny status zgromadzenia, pełny tekst Reguly Mikołaja IV), zaś pozostałe — hagiograficzną, zawierającą biografie świętych tradycyjnie związanych w III Zakonem: świętej Elżbiety Węgierskiej — księżnej ${ }^{18}$, małżonków — świętego hrabiego Elzeara i błogosławionej Delfiny ${ }^{19}$ oraz błogosławionego Iwona z Bretanii - prawnika i kapłana ${ }^{20}$. W ostatnim rozdziale $(O$ niektórych drugich świętych mężczyznach i białychgłowach tego trzeciego zakonu) wspomniani są ogólnie inni przedstawiciele stowarzyszenia, jak święty Ludwik IX król francuski ${ }^{21}$, małżeństwo błogosławionych Luchezjusza i Bonadonny ${ }^{22}$, a także święte Róża z Viterbo $^{23}$ czy Małgorzata z Kortony ${ }^{24}$ oraz związani z zakonem reprezentanci ducho-

\begin{abstract}
${ }_{18}$ Święta Elżbieta Węgierska (1207-1231), urodzona w Bratysławie lub Sárospatak, córka króla Węgier Andrzeja II. W wieku czterech lat wywieziona do Turyngii, gdzie w 1221 roku poślubiła landgrafa Ludwika. Zasłynęła z dzieł miłosierdzia, była wzorową małżonką i matką trojga dzieci. Po śmierci męża złożyła ślub wyrzeczenia się świata i osiadła w Marburgu, gdzie założyła szpital pod wezwaniem świętego Franciszka. Zmarła z wycieńczenia 17 listopada 1231 roku. Kanonizowana cztery lata później, w 1235.
\end{abstract} Zob. T. Słotwiński OFM, M. Damian OFM, dz. cyt., s. 487-488.

${ }^{19}$ Święty Elzear Sabran (ok. 1285-1323), hrabia Ariano, urodzony w Prowansji, w młodym wieku poślubił Delfinę Glandéves, z którą żył w dziewiczym małżeństwie. Oboje byli członkami Trzeciego Zakonu Świętego Franciszka. Prowadzili głębokie życie religijne i ascetyczne, pełnili uczynki miłosierdzia. Elzear zmarł 27 września 1323 roku w Paryżu, kanonizowany w 1369. Delfina przeżyła męża o trzydzieści pięć lat. Jej kult zatwierdzono w 1694 roku. Zob. tamże, s. 406-408.

${ }^{20}$ Święty Iwon (1253-1303), urodzony w Bretanii, studiował prawo i teologię. Po uzyskaniu święceń kapłańskich pełnił funkcję oficjała sądu biskupiego. Słynął ze sprawiedliwości, był rzecznikiem niesłusznie uciskanych i prześladowanych. Na własną prośbę został zwolniony z urzędu i objął probostwo, troszcząc się o potrzeby ubogich, chorych i samotnych. Był tercjarzem franciszkańskim. Zmarł 19 maja 1303 roku. Czczono go jako jednego z najbardziej popularnych świętych północnej Francji i patrona prawników. Kanonizowany w 1347 roku. Zob. tamże, s. 211-212.

${ }^{21}$ Święty Ludwik IX, król Francji (1214-1270), urodzony w Poissy, ukoronowany w wieku 12 lat, jeden z najbardziej znanych władców średniowiecza. Zakazał pojedynków i prywatnych wojen, fundował instytucje charytatywne, osobiście usługiwał potrzebującym. Prowadził skromne, ascetyczne życie. Należał do Trzeciego Zakonu franciszkańskiego. Zmarł w czasie wyprawy krzyżowej 25 sierpnia 1270 roku, kanonizowany w roku 1297. Zob. tamże, s. 356-357.

22 Błogosławiony Luchezjusz z Poggibonsi (1181-1260), urodzony w Gaggiano, kupiec, ożeniony z Bonadonną. Według tradycji, na ich prośbę święty Franciszek ułożył regułę życia ewangelicznego dla osób świeckich, dając początek Trzeciemu Zakonowi. Małżonkowie przywdziali habity tercjarskie i prowadzili życie w ubóstwie i pokorze, nacechowane miłością do innych. Są pierwszymi członkami Trzeciego Zakonu wyniesionymi na ołtarze. Luchezjusz zmarł w 1260 roku, ryt brewiarza i mszy świętej ku jego czci zatwierdzony został w 1694. Zob. tamże, s. 179.

${ }^{23}$ Święta Róża z Viterbo (1233-1252), urodzona w Viterbo, od dzieciństwa przejawiała skłonność do pobożności i ascezy. W wieku dziesięciu lat została tercjarką franciszkańską. Otwarcie występowała przeciwko cesarzowi walczącemu z papieżem. Uważano ją za wizjonerkę i cudotwórczynię. Zmarła w 1252 roku, kanonizowana w 1457. Zob. tamże, s. 372-373.

${ }^{24}$ Święta Małgorzata z Kortony (1247-1297), urodzona w Laviano, w szesnastym roku życia związała się z bogatym młodzieńcem, z którym żyła w nieślubnym związku przez dziewięć lat. Po tragicznej śmierci kochanka nawróciła się i wstąpiła do Trzeciego Zakonu Świętego Franciszka, rozpoczynając życie pokutnicy. Poświęciła się modlitwie, ascezie i uczynkom miłosierdzia. Udzielała pouczeń duchowych licznym 
wieństwa ${ }^{25}$. Duża liczba tercjarzy wyniesionych na ołtarze świadczy — jak konkluduje z przekonaniem autor — o pożytkach duchowych płynących z faktu przynależności do zgromadzenia:

[...] szczęśliwie postanowione było to ś‘więte) Bractwo abo zakon Braciej i Sióstr Pokutujących, który był sporządzony przez Ojca śswiętego Franciszka dla tego, żeby wszyscy Chrześcijanie wolni w stanie małżeńskim będący, wdowcy i wdowy, którzy nie mogą nosić obowiązku zakonnego, mogli w domach swych i po inszych miejscach osobnych czynić owoce godne pokuty dla dostąpienia zbawienia wiecznego i dla oddania czci powinnej Panu> Bogu wszechmogącemu ${ }^{26}$.

Rozdział wprowadzający czytelnika w genezę zakonu ma charakter stricte informacyjny i w swych inicjalnych partiach zdradza pokrewieństwo treściowe $\mathrm{z}$ fragmentem żywota świętego Franciszka Tomasza z Celano. Grupy tercjarzy powstają jako odpowiedź Biedaczyny na zapotrzebowanie laikatu na formę życia umożliwiającą dążenie do doskonałości:

Gdy rozsiewał wielebny Ociec ś‘więty’ Franciszek słowo abo nasienie żywota po włoskiej ziemi, upadło go niemało na serca ludzi małżeństwem związanych, którzy nie mogli iść wolnie za duchem pokuty jako pragnęli: a mieli taką do tego chuć, iż podczas całe osady chciały opuszczać wszystko, a iść za Ojcem świętym, który gorąco starał się o duszne zbawienie ludzkie. Gdy tedy Ojca świętego żądano, i owszem, mu się przykrzono [...], aby też był podał sposób i Regułę ludziom świeckim i w małżeństwie będącym na czynienie pokuty [...], w roku 1221 postanowił zakon pokutujących dla wszystkich powszechnie chrześcijan, którzy nie żyją w klasztorach ${ }^{27}$.

W dalszych fragmentach analizowanego rozdziału autor eksponuje postać Poverella jako założyciela i prawodawcy nowego zgromadzenia ${ }^{28}$, wskazując na istnienie pierwotnej, Franciszkowej reguły, zawierającej bliżej nie sprecyzowane normy dotyczące sposobu życia. W dalszych partiach swego wywodu, poświęconych obowiązującej współcześnie Regule Mikołaja IV, skrótowo przytacza najważniejsze ustalenia tego dokumentu. Wskazuje też na odrębność franciszkańskiego zakonu laików (mimo traktowania ich jako braci zakonnych) względem zgromadzeń o charakterze regularnym:

Wiedzieć też potrzeba, iż Bracia Mniejsi nie mogą przyjmować tych pokutujących na profesyją abo na posłuszeństwo zakonne ani na żaden ślub, ale tylo ich przypuszczać i pozwalać im do pomienionej Reguły żywota i towarzystwa pokutujących ${ }^{29}$.

odwiedzającym, między innymi Dantemu. Zmarła 22 lutego 1297 roku, nazwana została „franciszkańską Magdaleną". Kanonizowana w 1728 roku. Zob. tamże, s. 200-201.

${ }^{25}$ Do Trzeciego Zakonu Świętego Franciszka wstępować mogli (i nadal mogą) także przedstawiciele kleru: papieże, biskupi i kapłani diecezjalni.

${ }^{26}$ Kroniki trzech Zakonów..., s. 424.

${ }^{27}$ Tamże, s. 405-406.

${ }^{28} \mathrm{~W}$ świetle najnowszych badań nad powstaniem Trzeciego Zakonu święty Franciszek uważany jest raczej za inicjatora bractwa, aniżeli jego założyciela w ścisłym znaczeniu tego pojęcia. Przyjmuje się raczej fakt duchowego założenia zakonu, polegającego na zapoczątkowaniu przez Poverella pewnego ruchu pokutników, ostatecznie nazwanego Trzecim Zakonem, a później — Franciszkańskim Zakonem Świeckich. Termin institutor zastosowany w bulli Mikołaja IV Supra montem (1289) zatwierdzającej stowarzyszenie nie jest pojęciem jednoznacznym z fundator, wskazuje na świętego Franciszka jako na animatora i formatora ruchu. Zob. Źródta franciszkańskie ..., s. 2378.

${ }^{29}$ Kroniki trzech Zakonów..., s. 406. 
Przytoczona przez autora w całości Reguła stanowi interesujący dokument normatywny, o wartości poznawczej, pozwalający zrekonstruować styl życia i duchowość tercjarzy od momentu jego wprowadzenia po niemal koniec wieku XIX. Zawarta w pierwszej części tekstu apologia wiary katolickiej miała fundamentalne znaczenie propagandowe w okresie ukazania się Kroniki, to jest czasach kontrreformacji. Wstęp nawiązuje do motywu nauczania błądzących przez uczniów Chrystusa, które to zadanie przejął i kontynuuje Kościół katolicki, stojący na straży czystości wiary. Jest ona stałą, niezniszczalną podstawą chrześcijaństwa, bez której nikt nie może dostąpić zbawienia. Godnym spadkobiercą Apostołów okazuje się święty Franciszek w roli założyciela zakonu pokutniczego, pouczając słowem i świadcząc przykładem życia o prawdziwej wierze ${ }^{30}$. Tym samym bohater $z$ okresu średniowiecza nabiera swoistej aktualności w dobie nowożytnych sporów religijnych, zaś tercjarstwo i podobne mu bractwa stają się awangardą katolicyzmu w wydaniu laickim.

Reguta podzielona jest na dwadzieścia punktów, z których każdy precyzuje odmienne aspekty funkcjonowania stowarzyszenia. Wśród warunków przyjęcia na pierwszym miejscu stawia się wierność wierze katolickiej; zdradzający sympatie proheretyckie nie mogą zostać członkami zakonu ${ }^{31}$. W przypadku kobiet zamężnych dodatkowo wymagano zgody małżonka. Przełożeni zobowiązani byli do przeprowadzenia stosownego wywiadu na temat aktualnego sposobu życia kandydata, a także pouczenia go w kwestiach normatywnych. Przed podjęciem okresu próbnego należało zwrócić zabrane rzeczy ich właścicielom i pojednać się z bliźnimi. Po upływie roku, po zasięgnięciu opinii współbraci i wizytatora, przewidziany był obrzęd profesji wieczystej, potwierdzonej na piśmie ${ }^{32}$. Dalsze partie Reguly zawierają zalecenia dotyczące ubioru, uczestnictwa w rozrywkach, postów, życia religijnego. Mimo wielu obostrzeń niektóre spośród przepisów uwzględniają specyficzną sytuację zdrowotną czy społeczną braci i sióstr. Zgodnie z duchem franciszkańskiego ubóstwa, jego członkowie zobowiązani byli do noszenia jednakowych szarych strojów przypominających habity, z taniego materiału, bez jakichkolwiek oznak zbytku. Zakaz ten łagodzono w odniesieniu do osób zobowiązanych do ubierania się zgodnie z wymogami swego stanu, lokalnych zwyczajów, a także chorych ${ }^{33}$. Podobne dyrektywy formułowano w kwestii abstynencji i postów. Tercjarze unikali potraw mięsnych w poniedziałki, środy, piątki i soboty, za

\footnotetext{
${ }^{30}$ Tamże, s. 409.

${ }^{31}$ Tamże, s. 409: „[...] niech będą pilno wypytani z strony wiary katolickiej [...]. Przetrze jednak tego potrzeba pilno, aby kiedy heretyka jakiego abo podejrzanego z strony herezyjej [...] nigdy nie przyjmowano".

32 Tamże, s. 409: „[...] po roku, za radą niektórych braciej baczniejszych jeśliż będzie się im zdał godnym, niech będzie przyjęty takim sposobem, to jest, żeby przyobiecał przykazanie Pańskie zachować i dosyć czynić, jako przystoi, za przestępstwa, których by się przeciw temu sposobowi życia dopuścił, gdyby go wizytator w tym znajdował. A takowa jego obietnica przez pisarza pospolitego niech będzie tamże zapisana".

${ }^{33}$ Tamże, s. 409-410: „[...] z podłego sukna względem drogości i maści, nie do końca białego, ani też czarnego jednako niech będą odziewani [...], kożuchy ich wszelakie niech nie będą rzezane bądź otworzyste. Względem podłości sukna i względem kożuchów [...] wedle kondycyjej ich, a zwłaszcza na chore mając wzgląd i na zwyczaj krajów może być dyspensacyja”.
} 
wyjątkiem ciężarnych i chorych. W kwestii życia duchowego zalecano odmawianie — w łączności z kapłanami i zakonnikami — oficjum siedmiu godzin kanonicznych, w przypadku niemożności ich odprawienia - recytację określonej liczby tak zwanych pacierzy tercjarskich ${ }^{34}$. Wszystkich bez wyjątku obowiązywał zakaz uczestnictwa w biesiadach, tańcach czy publicznych widowiskach ${ }^{35}$ oraz zalecenie sporządzenia testamentu w czasie trzech miesięcy od momentu wstąpienia. Zabraniano - poza sytuacjami koniecznymi — noszenia i używania broni. Sytuacje konfliktowe wewnątrz wspólnoty miały być rozstrzygane zgodnie ze wskazaniami ordynariusza danej diecezji. Tercjarze mieli wystrzegać się składania uroczystych bądź prywatnych przysiąg bez wyraźnej potrzeby. Każdy zobowiązany był do troski o zgodę we wspólnocie i w życiu rodzinnym. W miarę możliwości należało uczestniczyć w codziennej mszy świętej, a raz w miesiącu w Eucharystii wspólnotowej i zebraniu. W czasie spotkania należało składać ofiary do wspólnej kasy na potrzeby ubogich i kościoła, w którym się zbierano. Raz w tygodniu odwiedzano chorych członków wspólnoty, wszyscy zobowiązani byli do uczestniczenia w pogrzebach oraz modlitwach w intencji zmarlych braci i sióstr. Urzędy (na przykład przełożonego) miały charakter czasowy i powinny być sumiennie pełnione. Corocznej wizytacji dokonywał duchowny z Zakonu Braci Mniejszych bądź inny uprawniony kapłan, wyznaczony przez przełożonych tego zgromadzenia. W przypadku poważnych wykroczeń — o których przełożeni zobowiązani byli informować wizytatora - po trzykrotnym upomnieniu następowało wydalenie z zakonu.

Część biograficzna, zawierająca trzy wymienione wyżej żywoty oraz wzmianki uzupełniające na temat innych bohaterów Trzeciego Zakonu, skonstruowana jest zgodnie z wymaganiami stawianymi żywotopisarstwu czasów potrydenckich. Jednym z celów ówczesnej hagiografii, dynamicznie rozwijającej się na skutek zapotrzebowania na literaturę katolicką, było propagowanie wzorców świętych należących do różnych stanów społecznych. Wynikało to, między innymi, z silnie zarysowującej się w tamtych czasach świadomości odbiorcy ${ }^{36}$ oraz przekonania o skuteczności oddziaływania nań pewnych form narracyjnych, w tym właśnie biografistyki ${ }^{37}$. Autorzy żywotów nie tylko zachęcali do oddawania czci świętym, ale pobudzali do ich naśladowania, stawiając przed oczyma czytelników parenetyczne modele chrześcijańskiego życia, możliwego

\footnotetext{
${ }^{34}$ Tamże, s. 410: „Niech zawsze odprawuje każdy siedm godzin kościelnych, to jest jutrznią, prymę, tercję, sextę, nonę, nieszpory i kompletę [...], nieumiejący pisma za jutrznią 12. pacierzy, a za każdą inną z godzin po 7, przydając Gloria Patri za każdym pacierzem. Do prymy i do komplety niech przydają Credo apostolskie i psalm Miserere mei Deus [...]".

35 Tamże, s. 410: „Na nieuczciwe biesiady i dziwowiska także do dworów i na tańce chodzić zgoła niech im zakazano będzie. Błaznom abo zapatrzenie na takie próżności nic niech nie dają [...]”.

${ }^{36}$ Adresat hagiografii nie ograniczał się już tylko do wąskiego kręgu wykształconych humanistów; starano się trafić do jak najszerszej publiczności literackiej, stąd zastosowana w dziele Skargi i innych zbiorach hagiograficznych zasada „na każdy stan”. Wiązał się z tym też fakt popularyzowania żywotów w językach narodowych (między innymi poprzez działalność translatorską) oraz rezygnacja ze zbyt kwiecistego stylu. Zob. A. Ceccherelli, Od Suriusa do Skargi. Studium porównawcze o „Żywotach świętych”, przekł. M. Niewójt, Izabelin 2003, s. 53-54.

${ }^{37}$ Tamże, s. 54.
} 
do zrealizowania przez przedstawicieli różnych profesji. Zaznaczającą się od XVI stulecia tendencją było tworzenie żywotów typu „imitandus”, przeciwstawiających się średniowiecznej formule "admirandus non imitandus”, według której życie świętego, wzbudzające podziw niezwykłością (na przykład wysiłków ascetycznych), wypełnione cudownymi zdarzeniami, stawało się trudne do zaakceptowania ${ }^{38}$. Doskonale zdawali sobie z tego sprawę luminarze staropolskiej hagiografii, jak Piotr Skarga, pisząc w przedmowie do swych Żywotów świętych:

[...] bo jak długa suknia karlikowi nie służy, tak zbytnie karności ciała, gdy kto nie ma osobnego daru do Boga i wzrostu nie ma, brane być nie mają. Bowiem albo jemu zdrowie starga, albo zacząwszy je nie wytrwa i we wszytkim osłabnie, albo na drugą stronę [...] od niedobierania do przebrania pójdzie, bo jako mądrzy doktorowie mówią: w świecie wszystkiemu się dziwować, ale nie wszytkiego naśladować możem³ ${ }^{39}$.

Rezultatem tak przyjętego rozumowania było konstruowanie biografii, w których odsuwano na dalszy plan epizody nacechowane fantastyką. Bohater wiary czasów potrydenckich charakteryzowany był poprzez pryzmat aktywności ukierunkowanej na Boga i bliźniego, nieugięty w swych przekonaniach przekładających się na konkretne czyny, dążący od zła ku dobru ${ }^{40}$. Opisy tych dokonań stanowiły w omawianej literaturze dominantę przekazu narracyjnego (,święte nie słowem cię namawiają, ale działaniem i czynieniem" - pisze w innym miejscu swej Przedmowy do Żywotów Piotr Skarga $)^{41}$. „Niema retoryka” jednostkowych czynów bohaterów przeciwstawiana była przekazowi słownemu i — w opinii żywotopisarzy XVI i XVII wieku — skuteczniejsza od lektury Biblii czy słuchania kazań ${ }^{42}$.

Najobszerniejszym tekstem hagiograficznym rozpatrywanego fragmentu Kroniki jest żywot świętej Elżbiety Węgierskiej, uważanej za główną patronkę Trzeciego Zakonu. Jakkolwiek formalna przynależność księżnej do stowarzyszenia nie została oficjalnie potwierdzona, wiadomo, iż landgrafini Turyngii pozostawała w kręgu oddziaływania duchowości franciszkańskiej i do dziś czczona jest we wspólnotach żyjących duchem Biedaczyny z Asyżu ${ }^{43}$. Obszerny biogram podzielony jest na pięć części, odpowiadających rozdziałom od piątego do dziewiątego analizowanej księgi. Konstruowaniu postaci bohaterki przyświeca wyżej omówiona zasada stworzenia wzorca osobowego do naśladowania („imitandus”). Rezultatem jej zastosowania jest wysunięcie na plan pierwszy licznych przejawów aktywności Elżbiety, manifestowanej w różnych dziedzinach życia tak wewnętrznego, jak i zewnętrznego. Aktywność ta, kreślona według aktualnego wówczas schematu narracji, czyli „wędrówki” ku doskonałości (od książęcych

\footnotetext{
${ }^{38}$ K. Sokołowska, $d z$. cyt., s. 33.

${ }^{39}$ Tamże, s. 33.

${ }^{40}$ H. Dziechcińska, Biografistyka staropolska w latach 1427-1627. Kierunki i odmiany, Warszawa 1971, s. 129.

${ }^{41}$ K. Sokołowska, $d z$. cyt., s. 32.

${ }^{42}$ A. Ceccherelli, dz. cyt., s. 54.

${ }^{43}$ R. Prejs OFMCap, Czy św. Elżbieta byta tercjarką? Rysy franciszkańskie w duchowości św. Elżbiety, [w:] Franciszku, idź i odbuduj Kościót mój! Materialy pomocnicze do formacji ciagłej dla FZŚ w Polsce na rok 2008. Materialy z VII Kapituly Narodowej FZŚ Warszawa 19-21 października 2007, Warszawa 2007, s. 115-124.
} 
splendorów do franciszkańskiego ubóstwa) znajduje swój wyraz w formach takich, jak modlitwa i asceza, skromność i pokora, miłosierdzie i posłuszeństwo. Prezentacja losów oraz czynów księżnej służy uzasadnieniu jej wyjątkowości, przy czym jest to ideał możliwy — przynajmniej w pewnym stopniu — do przyjęcia przez czytelnika. Centralna postać opowiadania jawi się w analizowanym tekście jako wzorcowa nosicielka cnót zalecanych odbiorcy, zwłaszcza związanemu z wyżej omawianą formacją religijną. Na podkreślenie zasługuje też uniwersalizm postaci Elżbiety, realizującej swoje powołanie do świętości w trzech stanach życia: panieńskim, małżeńskim i wdowim, zgodny z zasadą „na każdy stan” przyświecającą hagiografii czasów potrydenckich ${ }^{44}$.

Zasadniczym elementem określającym dyskutowany wzorzec osobowy jest miłość Boga, przejawiająca się w praktykowaniu modlitwy, uważanej za fundament życia chrześcijańskiego i główne znamię świętości. Zgodnie z założeniem autora, aktywność religijna możliwa jest w każdym stanie, co znajduje potwierdzenie na każdym etapie biografii Elżbiety. Modlitwa określa zasadniczy profil doskonałości młodej księżniczki, o czym świadczy posłużenie się przez autora znanymi już z hagiografii średniowiecznej toposami, jak puer senex: „w młodych jeszcze leciech poczęła pogardzać światem”45, „[...] chuci dziecińskie odmieniała w chuci do służby Bożej”46. Na uwagę zasługuje częściowa zbieżność wspomnianych w tekście ćwiczeń duchowych z formami pobożności zalecanymi Reguta Trzeciego Zakonu — „nie zaniechała też upominać i swoich służebnych panien do odprawiania psalmów” ${ }^{\text {47 }}$, „nie opuszczała też nigdy zwyczajnych swoich pacierzy" ${ }^{48}$. Postawa Elżbiety — orantki przyczynia się do zmiany nastawienia niechętnego jej otoczenia, a także małżonka, który z czasem staje się współuczestnikiem świętości księżnej — rzecznikiem jej działalności dobroczynnej, w końcu uczestnikiem krucjaty. Aktywność religijna centralnej postaci dyskursu ulega, w miarę odchodzenia od spraw ziemskich, stopniowej intensyfikacji. Prowadząc swą bohaterkę ku wyżynom świętości, autor wskazuje i podkreśla fakt osiągania przez nią coraz wyższych stopni modlitwy — od ustnej, charakteryzującej okres dzieciństwa i młodości, do kontemplacyjnej, wieńczącej ostatnie etapy życia duchowego landgrafini. W toku dyskursu hagiograficznego oznacza to stopniowe przechodzenie od ogólnikowych sformułowań w rodzaju: „poważnie pilnowała modlitwy w kościele”49 do rozbudowanych pod względem narracyjnym opisów:

Będąc [...] jednego dnia w kościele, wlepiła tak oczy w ołtarz, iż znać dała po sobie, że patrzyła na majestat Boski: i trwała tak przez kilka godzin, mając na ten czas objawienie z nieba, a wróciwszy się do domu, dla zemdlenia musiała się położyć $[\ldots]^{50}$.

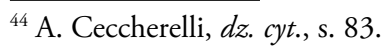

${ }^{45}$ Kroniki Trzech Zakonów..., s. 414.

${ }^{46}$ Tamże, s. 414.

${ }^{47}$ Tamże, s. 414.

${ }^{48}$ Tamże, s. 414.

${ }^{49}$ Tamże, s. 414.

${ }^{50}$ Tamże, s. 419.
} 
Uwiarygodnianiu duchowych doświadczeń Elżbiety służy zabieg cytowania jej wypowiedzi, zanotowanych w dostępnych hagiografowi źródłach literackich ${ }^{51}$. Marek z Lizbony przytacza modlitwy księżnej, wypowiadane w różnych okolicznościach, jak śmierć ukochanego małżonka czy perspektywa oddalenia potomstwa. Z tekstów tych wyłaniają się, pośrednio, inne aspekty świętości bohaterki, przydające aktualności jej postaci. Są nimi: miłość oraz wierność małżeńska, a także matczyne przywiązanie do dzieci ${ }^{52}$. Pewne zdarzenia, skonkretyzowane w formie egzemplów-obrazków, jak wybawienie matki Elżbiety z czyśćca, nawrócenie lekkomyślnie żyjącego młodzieńca czy przywrócenie mowy choremu, wskazują na skuteczność modlitwy wstawienniczej. Żywot akcentuje także towarzyszące modlitwie zewnętrzne gesty Elżbiety, świadczące o jej szacunku do Eucharystii, wykorzystując popularny epizod zapisany w dawnych przekazach: ,gdy Ewanjeliją czytano, śpiewano abo mówiono, zdejmowała rękawice i klejnoty z głowy i kładła się na ziemi, czcząc przez to Pana swego" ${ }^{33}$. Związane z postawą religijną praktyki ascetyczne przedstawione są w formach nie przekraczających możliwości odbiorcy, zaś ich prezentacja sprowadza się do wyliczeń konkretnych czynności, jak oszczędne odżywianie się, poświęcanie pewnej ilości czasu na modlitwę nocną (bez uchybiana, jednakże, obowiązkom małżeńskim $)^{54}$, stosowanie dyscypliny — nie będące jednakże celem samym w sobie, lecz podyktowane pragnieniem łączności z męką Chrystusa.

Obok wyżej wymienionych, do najczęściej eksponowanych walorów bohaterki należą — zalecane także świeckim naśladowcom Poverella — pokora i ubóstwo. W hagiografii omawianego okresu posiadają one szczególny walor zasługujący, zwłaszcza gdy praktykowane są przez osoby należące do wyższych warstw społecznych. Sformułowana przez autora teza: „Acz była w wielkim stanie i acz się jej w doczesnych rzeczach powodziło, więcej jednak pragnęła stanu ubóstwa" 55 znajduje potwierdzenie w szeregu zdarzeń ilustrujących linię postępowania Elżbiety, także w relacji do otoczenia. Wzrastająca w nacechowanym negatywnie środowisku dworu księżna od początku przyjmuje wobec niego postawę kontestatorki: „Pierwszego roku zażyła wiele trudności od męża swego: bo acz on sam był skłonnym do dobrego, jednak za złą radą dworzan swych [...], którzy rozumieli, iż pokora ona wielka tej tak zacnej Paniej barzo nie przystała i owszem z sromotą [...] dworu wszystkiego była, gardzili nią i prześladowali [...]" ${ }^{56}$. Również dalsze partie żywota stawiają bohaterkę wobec podobnych

\footnotetext{
${ }^{51}$ Zanotowana na marginesie żywota Legenda, będąca podstawowym źródłem biograficznym Marka z Lizbony, zdradza pokrewieństwo z innymi przekazami biograficznymi, jak na przykład Zeznaniami czterech stużacych - dokumentem powstałym na potrzeby procesu kanonizacyjnego, zawierającym świadectwa towarzyszek życia świętej Elżbiety i przytoczenia adresowanych do nich wypowiedzi księżnej. Zob. Elisabeth von Thüringen - eine europäische Heilige. Aufsätze. Hrsg. von D. Blume und M. Werner, Petersberg 2007, s. 187-192.

52 Kroniki trzech Zakonów..., s. 417: „Wielceć dziękuję, Panie, iżeś mi dał oglądać ciało małżonka mego [...]. Ty wiesz dobrze, jakomci go miłowała, iż też on miłował i bał się ciebie [...], i aczbym barzo rada była z nim mieszkała [...], polecam teraz duszę jego i moje łasce Twojej świętej”.

${ }^{53}$ Tamże, s. 414.

${ }^{54}$ Tamże, s. 415.

55 Tamże, s. 415.

${ }^{56}$ Tamże, s. 414.
} 
zmagań, określanych przez autora mianem „wojny”, z której wychodzi zwycięsko dzięki swej determinacji:

[...] Arcybiskup jeden, wuj jej, który bacząc [...], że toż do takiego ubóstwa przyszła była, umyślił ją wydać za męża, [...] lecz gdy [...] mocno postanowiła pierwej umrzeć, niż za mąż iść, [...] dał jej Pan Bóg i w tej wojnie zwycięstwo ${ }^{57}$.

Cytowany żywot nierzadko umieszcza postać centralną w towarzystwie anonimowych służebnych i biedoty, przy wspólnym stole czy prostych czynnościach, jak przędzenie wełny ${ }^{58}$. Inną odmianą prezentacji tego aspektu świętości są partie opisowe, ukazujące sposoby utożsamiania się Elżbiety z przedstawicielami niższych warstw społecznych. Najbardziej jaskrawym przejawem owej solidarności jest ubiór, poddany przez autora żywota detalicznemu oglądowi:

[...] ubierała się częstokroć jak uboga żebraczka; co osobliwie na ten czas czyniła, gdy sama ze swymi przyjaciółmi i służebnicami w domu mieszkała, powiadając: iżby tak chodziła, gdyby do ubóstwa przyszła. Na procesyje i na litanije więtsze zawsze boso chadzała, ubrawszy się w płócienne tylko szaty [...]. Uczyniwszy ślub [wyrzeczenia się świata - B. P.-D.], przyjęła habit Pokutujących trzeciego zakonu śswiętego’ Franciszka i przyjąwszy na się suknią i płaszczyk z grubego sukna, połatane wszędzie, ślubowała posłuszeństwo przed spowiednikiem $[\ldots]^{59}$

Najbardziej spektakularny przejaw świętości postaci tytułowej to czyny miłosierdzia, wypełniające obszerne partie rozdziałów ósmego i dziewiątego. Przybierając formę opisu konkretnych czynów przejętych z dawnych żywotów bądź prezentacji o charakterze uogólniającym, stanowią rozwinięcie kolejnej tezy hagiografa:

$\mathrm{Z}$ tego źródła miłości boskiej wynikały ustawicznie na dusze jej żywe wody uczynków miłosiernych [...]. W braniu rzeczy na swą potrzebę barzo była ścisła i skąpa, lecz przeciw ubogim tak była hojna, iż nie chciała, aby im czego miało nie dostawać, dla której cnoty nazywali ją poddani [...] matką ubogich ${ }^{60}$.

Rezygnując z elementów charakterystycznych dla opisu epickiego (szczegółowych danych dotyczących lokalizacji miejsc akcji, adresatów działalności świętej, chronologii zdarzeń), autor koncentruje się na prezentacji szerokiego repertuaru czynności, występujących w charakterze „przykładów miłosierdzia" ${ }^{1}$ : „dała raz szatę swą ubogiej białogłowie” ${ }^{2}$, „gdy nie miała pieniędzy, poprzedawszy swe klejnoty, dogodziła potrzebnym" ${ }^{63}$. Sposób prezentacji aktów dobroczynności — niekiedy zawierający drastyczne szczegóły - pozwala na ujawnienie także innych walorów postaci tytułowej, jak przezwyciężanie naturalnych odruchów wstrętu („służyła im [...] z dziwną

\footnotetext{
${ }^{57}$ Tamże, s. 417.

58 „Nie dała się swoim wychowanicom i ubogim nazywać panią, ale z nimi postępowała jako z sobie równymi: z nimi pospołu jadała, przędła i inne roboty odprawowała; a tak się kochała w pokorze, iż żadną się posługą nie brzydziła i nie dopuszczała sobie służyć dla miłości Bożej”. Zob. tamże, s. 415.

${ }^{59}$ Tamże, s. 415, 418.

${ }^{60}$ Tamże, s. 416.

${ }^{61}$ H. Dziechcińska, dz. cyt., s. 132.

${ }^{62}$ Kroniki trzech Zakonów..., s. 416.

${ }^{63}$ Tamże, s. 417.
} 
pokorą, znosząc z wielką cierpliwością smród [...]") ${ }^{64}$ czy wykorzystywanie okazji do umartwień („Po całych nocach nie sypiała, dogadzając chorym” ${ }^{65}$. W wymienionych kontekstach przywoływane są także zdarzenia cudowne, prezentowane o tyle, o ile służyć mają konkretnemu „pożytkowi” i celom parenetycznym (uzdrowienie chorego za pomocą modlitwy, połów ryb z zamarzniętej rzeki, mający przekonać o sile wiary). $\mathrm{Z}$ reguły jednak w hagiografii XVI i XVII wieku cuda przestają być pierwszorzędnymi elementami narracji; przesłaniają je opisy bardziej realnych czynów, bliskich bądź zbliżonych do doświadczenia odbiorcy. Według Piotra Skargi, „nie na cudach, ale na cnotach pobożności wszelakiej doskonałość chrześcijańska należy"66.

Elżbieta to także wzorowe ucieleśnienie posłuszeństwa, przybierającego w biografii dwie postacie: akceptację woli Boga i uległość wobec ludzi kierujących jej życiem. Zgodnie z przyjętą przez autora strategią, postawy te cechują już okres dzieciństwa i młodości. Komentując fakt zawarcia przez księżniczkę małżeństwa wbrew własnej woli $^{67}$, autor niejako „usprawiedliwia” go posłuszeństwem wobec wyroków Opatrzności i ziemskiego ojca, jak również koniecznością zaprowadzenia stanu harmonii pomiędzy skłóconymi społecznościami. Identyczną dyspozycję Elżbiety, przyjmującej przeznaczony sobie los bez zastrzeżeń, obserwujemy w opisie okresu po śmierci małżonka. Postawa rezygnacji z własnej woli i upodobań cechuje całe życie bohaterki, przygotowując ją do znoszenia najcięższych prób. Jednym z częściej wykorzystywanych zdarzeń biografii świętej jest — obecny już w średniowiecznych świadectwach tekstowych — wątek wygnania młodej wdowy z zamku, tutaj przytaczany jako dowód poddania się woli Bożej i męstwa w znoszeniu przeciwności:

[...] skoro się dowiedzieli o śmierci Landgrafa męża jej powinni i poddani, zaraz ją wygnali z pałacu [...]. I tak jej wszyscy za tym odstąpili, iż na noc przyszła, nie mając gdzie by się było przytulić, jako wygnańca udała się do jednego chlewa, kędy bydło stawało, dziękując z radością wielką Panu swemu, że jej dał doczekać takiego stanu. [...] wiele krzywd i urągania od powinnych zmarłego męża i od poddanych z weselem wielkim i z cierpliwością niewymowną przyjmując i za wielką to łaskę od Pana mając ${ }^{68}$.

Modelowym przykładem posłuszeństwa jest także relacja Elżbiety ze spowiednikiem, Konradem z Marburga, posiadająca charakter całkowitej (a zatem wzorcowej) zależności kierowanej od kierującego, co podkreślone jest z całym naciskiem: „tak zupełnie rady jego zachowała we wszystkich rzeczach, aż też przykrych" ${ }^{69}$. W celu poparcia swego założenia hagiograf powołuje się na przywoływa-

\footnotetext{
${ }^{64}$ Tamże, s. 417.

${ }^{65}$ Tamże, s. 417.

${ }^{66}$ Tamże, s. 59.

${ }^{67}$ Według najnowszych ustaleń, Elżbieta nie miała pragnienia pozostawania w dziewictwie; zdaniem J.I. Adamskiej, wydana za mąż w czternastym roku życia, darzyła małżonka autentycznym uczuciem i była zadowolona z każdego stanu, w jakim aktualnie się znajdowała. Źródła biograficzne zanotowały gwałtowną reakcję emocjonalną świętej na wieść o śmierci Ludwika: „Umarł dla mnie świat i jego radości!”. Zob. J. I. Adamska OCD, Miłosierdzie, ubóstwo, radość. Rzecz o świętej Elżbiecie Węgierskiej, księżnej turyńskiej, Poznań 2002, s. 57, 107.

${ }^{68}$ Kroniki trzech Zakonów..., s. 417.

${ }^{69}$ Tamże, s. 415.
} 
ny w licznych przekazach wydany przez Konrada zakaz używania potraw pochodzących z dóbr zagrabionych Kościołowi i ubogim. Księżna przestrzegała tego polecenia z całą konsekwencją i pełną świadomością dokonanego przez siebie wyboru:

Za tym posłuszeństwem i mając też sumnienie, nie chciała się dotykaćani też zażywaćżadnej rzeczy z dochodów [...] urzędników Pana swego nabytych, bojąc się, aby ono nie było krwią ubogich poddanych"70.

Osobny akapit poświęcony jest także łączności księżnej z Zakonem Braci Mniejszych; będąca duchową córką franciszkanów Elżbieta chętnie spotyka się z nimi i prowadzi braterski dialog, powierzając zakonnikom swoje rozterki wewnętrzne. $\mathrm{Z}$ wypowiedzi, przytoczonej w pierwszej osobie, wyłania się bliski odbiorcy portret landgrafini, zmagającej się z własną grzesznością, świadomej swych niedoskonałości ${ }^{71}$.

W obszernej prezentacji ostatnich chwil życia bohaterki autor wykorzystuje wszystkie budujące czytelnika elementy, jak fakt przyjęcia ostatnich sakramentów, przygotowanie wszystkich przedmiotów potrzebnych do pogrzebu, motyw odrzucenia pokusy szatańskiej. Potwierdzeniem świętości Elżbiety są cuda pośmiertne, nie poddawane jednakże szczegółowemu oglądowi, autor poprzestaje na ogólnych wyliczeniach typu: przywracanie wzroku, uzdrawianie ułomnych, oczyszczanie trędowatych, wskrzeszanie zmarłych $^{72}$. Informacja na temat procesu kanonizacyjnego i wyniesienia księżnej na ołtarze stanowi dopełnienie żywota.

Zbliżoną poetyką odznaczają się, następujące po żywocie świętej, znacznie mniej rozbudowane biografie Elzeara i Delfiny oraz Iwona z Bretanii. Ich bohaterowie wykazują oznaki wyjątkowości od młodych lat, skonkretyzowane w formach znanych hagiografii: posty, modlitwa, unikanie okazji do grzechu i troska o potrzebujących. W przypadku świętej pary małżeńskiej, pozostającej w związku dziewiczym, szczególny nacisk położony jest na praktykę czystości cielesnej i duchowej: Elzear „nigdy się do spania nie rozbierał; a we dnie też zawsze używał włosiennice [...]"73. Wpleciony w tekst komentarz odautorski wskazuje na aktualność prezentowanego wzoru, zachęcając odbiorcę do naśladowania:

godzien taki żywot i taka cnota ich wielkiego zalecenia, bo rzadka jest: i słuszna jest, abyśmy jej naśladowali przynajmniej po części; gdyż grzech sprośny jej przeciwny do wiela złego przywodzi ${ }^{74}$.

O stałości podjętego postanowienia świadczy, podkreślany przez autora, fakt pozostawania małżonków w czystości przez 27 lat ${ }^{75}$. Czyny miłosierdzia, spełniane w duchu służby Chrystusowi, postrzeganemu w ubogich i chorych, stanowią dodatkowy tytuł do świętości Elzeara: podobnie jak księżna Turyngii, nie waha się on przed

\footnotetext{
${ }^{70}$ Tamże, s. 415.

${ }^{71}$ Tamże, s. 416: „[...] rozumiem, że dla grzechów moich nie godnam miłości u Boga, i acz ustawicznie staram się, ile mogę, i ze wszystkich sił moich, abym go miłowała; jednak przecie boję się, aby mię od siebie nie odrzucił jako tej, któram niegodna jego miłości i obecności”.

72 Tamże, s. 420.

${ }^{73}$ Tamże, s. 421.

${ }^{74}$ Tamże, s. 421.

75 Tamże, s. 421.
} 
spełnianiem wobec nich najniższych posług, z umywaniem nóg trędowatym włącznie ${ }^{76}$. Efekt podobieństwa do konstrukcji postaci św. Elżbiety osiągnięty zostaje poprzez akcentowanie innych, identycznych form dobroczynności (wspieranie biednych, karmienie głodnych), a także postawy męstwa w znoszeniu krzywd ze strony przeciwników. Sposób ukazania losów małżonki bohatera zmierza do utrwalenia w świadomości odbiorców ideału wdowy: Delfina nie decyduje się na powtórne zamążpójście, trwa w bogomyślności i wierności zmarłemu małżonkowi (a także regule franciszkańskiej), a po śmierci zostaje pochowana w habicie swego zakonu, w miejscu spoczynku swego towarzysza życia.

Zamieszczona w dalszej części interesującego nas wywodu biografia świętego Iwona przybliża postać prawnika i duchownego, wzorowo spełniającego obowiązki swego stanu. Pierwsza część przekazu, omawiająca „świecki” rozdział życia bohatera, kładzie nacisk na gruntowne wykształcenie, zdobywane w sławnych ośrodkach (Paryż), umiejętność przekazywania wiedzy innym oraz cnoty zalecane potencjalnym naśladowcom: sprawiedliwość w sądzeniu, bezinteresowność („taką czynił sprawiedliwość nie bacząc na nikogo [...] nie chciał nigdy żadnej nagrody brać za swe prace w tym urzędzie") ${ }^{77}$. Okres „kapłański” znamionuje praktyka ubóstwa, umartwienie (noszenie włosiennicy), praktyki ascetyczne (posty, rezygnacja ze snu), nabożne sprawowanie mszy świętej, konsekwencja w odmawianiu brewiarza, miłosierdzie ${ }^{78}$.

W dziele Marka z Lizbony zaobserwować można interesującą i dogłębną analizę fenomenu świętości. Jest ona, jak wynika z przeprowadzonych obserwacji, dostępna i zalecana nie tylko przedstawicielom stanu duchownego, lecz także osobom świeckim. Jako taka posiada wymiar uniwersalny. Kroniki trzech Zakonów portugalskiego franciszkanina wpisują się tym samym w nurt literatury religijnej propagującej wartości możliwe do osiągnięcia dla wszystkich. W części normatywnej wskazują środki służące dążeniu do doskonałości, zaś w biograficznej —wzorce praktycznego postępowania zgodnego z duchem Biedaczyny z Asyżu.

\section{Charism and Saints of the Third Order of St. Francis in Chronicles of the Three Orders by Marco da Lisboa from 1610}

\section{Summary}

The aim of the article is to present the charism and role models of the Third Order of Saint Francis of Assisi as described in the chronicles of the Order of the Friars Minor by Marco da Lisboa and translated into Polish in 1610. The ninth chapter of the second volume of the book contains interesting material divided into two parts. The first one is dedicated to the history of the Third Order, its rules and relating papal documents, while the second is a selection of the lives of saints belonging to the Order, such as St. Elizabeth of Hungary. The material under discussion allows the reader to reconstruct the structure of the Third Order in the $17^{\text {th }}$ century and study the role models recommended to its members.

\footnotetext{
${ }^{76}$ „dla miłości Chrystusowej częstokroć sam obmywał wrzody trędowatych [...], jakby właśnie w nich patrzył i usługiwał samemu Chrystusowi”. Zob. tamże, s. 421.

77 Tamże, s. 421.

${ }^{78}$ Tamże, s. 423: „Obrządek Boski odprawował z wielką pilnością i nabożeństwem; a o północy zawsze wstawał na Jutrznią: we dnie odprawował godziny wszystkie wedle swego czasu”.
} 